\title{
Confused branding? An exploratory study of place branding practices among place management professionals
}

\section{Ivo}

ivodenoronha@gmail.com

\section{J. Andres Coca-Stefaniak ${ }^{\mathrm{b}, *}$}

a.coca-stefaniak@gre.ac.uk

Alastair M.

alastair@purdue.edu

aStrategic Solutions (Int.) Ltd., 12 Manchester Court, Victoria Docks, London E16 3GZ, United Kingdom

bUniversity of Greenwich, Department of Marketing, Events and Tourism, Business School, Old Royal Naval College, Park Row, London SE10 9LS, United Kingdom

${ }^{\mathbf{c}}$ Purdue University, Department of Hospitality and Tourism Management, College of Consumer \& Family Sciences, Room 111A, Stone Hall, West Lafayette, IN 47907-2059, USA

${ }^{*}$ Corresponding author

Abstract

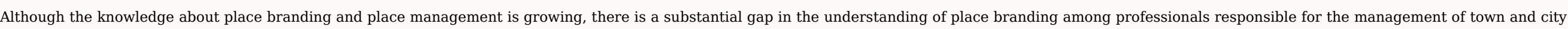

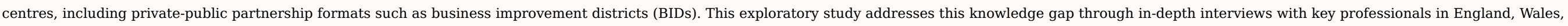

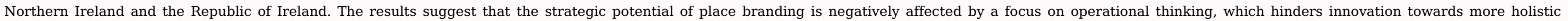

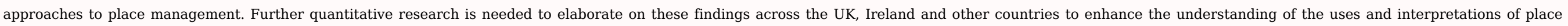
branding among town and city managers.

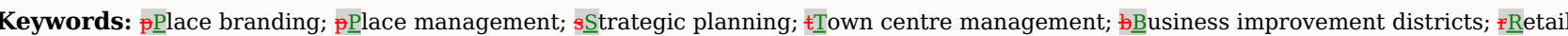

\subsection{Introduction}

\subsubsection{Background}

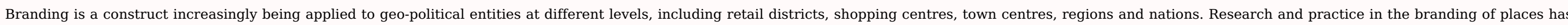

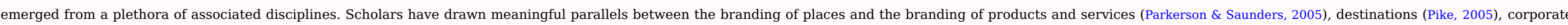

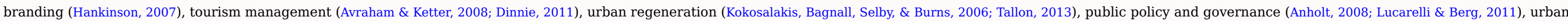
planning (Costaglioli \& Van Assche, 2012) and place marketing (Dinnie, Melewar, Seidenfuss, \& Musa, 2010; Gertner, 2011; Kavaratzis, 2004).

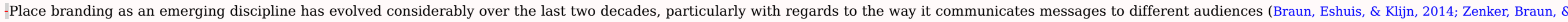

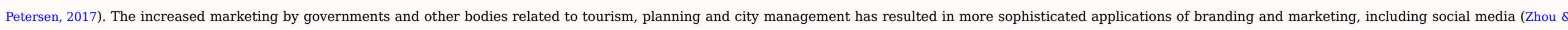

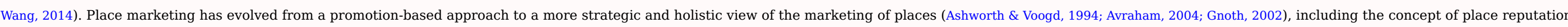

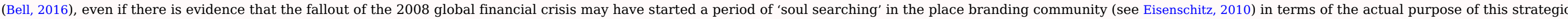

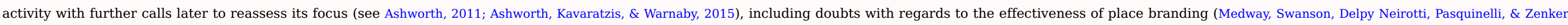
2015). 


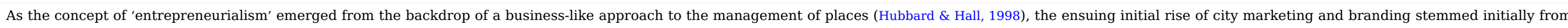

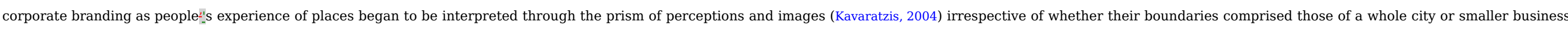

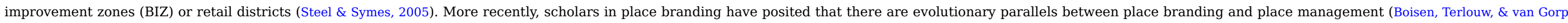

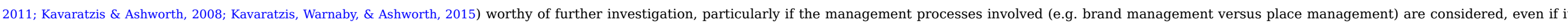

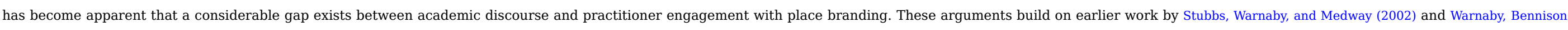

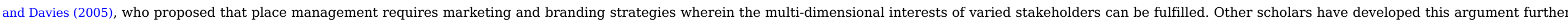

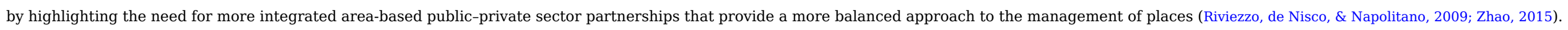

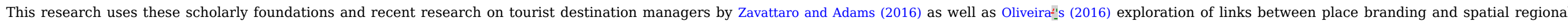

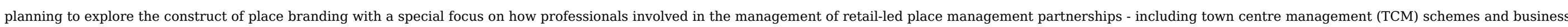
improvement districts (BIDs) - interpret its use in practice. The focus of this study on professionals involved with BIDs and TCM partnerships renders it a first of its kind in place branding.

\subsubsection{Conceptual framework for research}

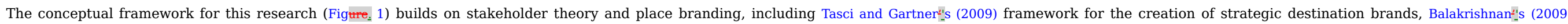

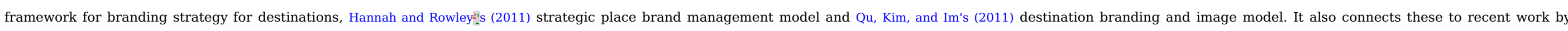
Foroudi et al. (2016) linking place branding, place image and place reputation, as well as Oliveira

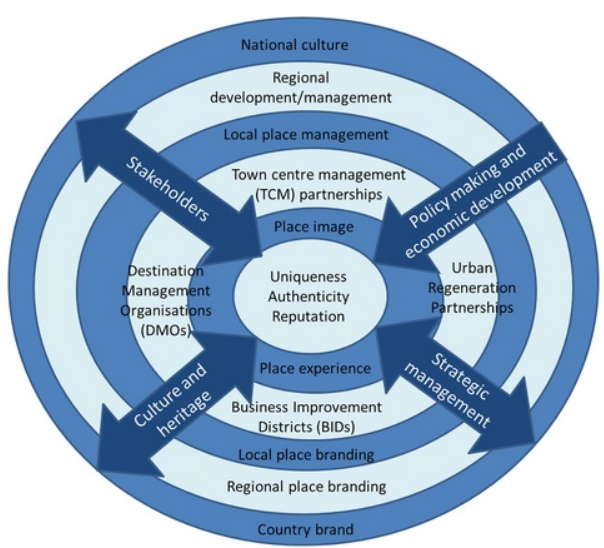

Figure 1,Fiq. 1 Conceptual framework for research.

\section{alt-text: Fig. 1.}

\subsubsection{Research aim and objectives}

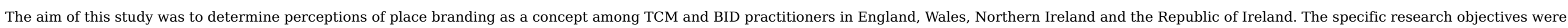

a) To identify the role of place branding in the management of TCM schemes and BIDs.

b) To examine the mechanisms used by place management professionals to implement place branding on the ground, including working with local stakeholders.

c)-_To evaluate potential avenues for the future of place branding in TCM and BIDs.

\subsection{Literature review}




\subsubsection{Place branding}

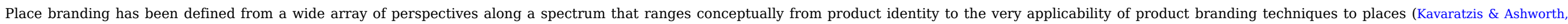
2006), including spatial interpretations of places, which include countries, regions and cities, among others (Ashworth et al., 2015; Chan \& Marafa, 2013).

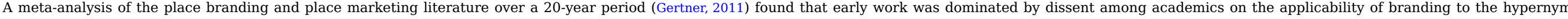

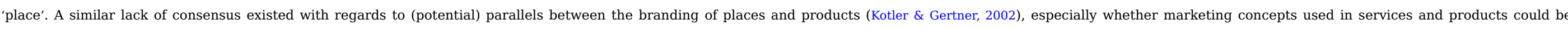

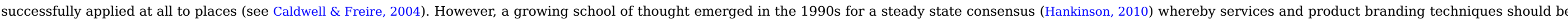
investigated with regards to their applicability to places (Skinner, 2008). This historical evolution of thought was summarised by Hankinson (2010), as shown in Figure. 2.

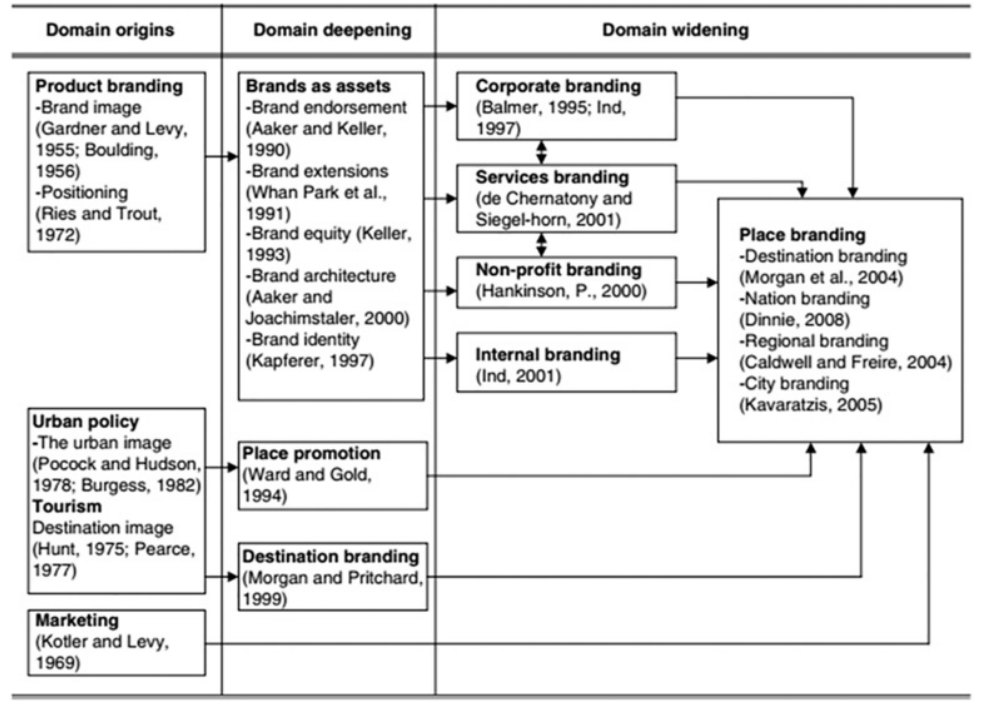

Figure 2.Fiq. 2 Historical timeline of the evolution of place branding as a research discipline (Hankinson, 2010)

\section{alt-text: Fig. 2.}

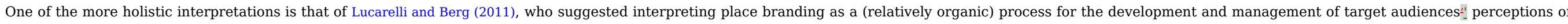

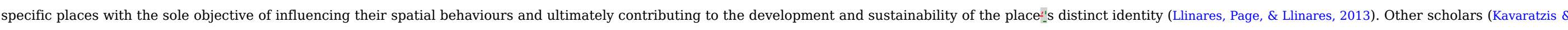

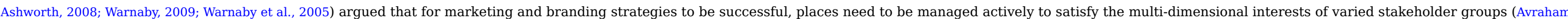
\& Ketter, 2008; Jackson, 2008). This issue of place management and its connection to place branding is explored next.

\subsubsection{Place management}

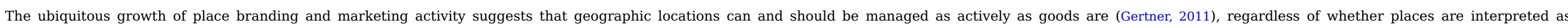

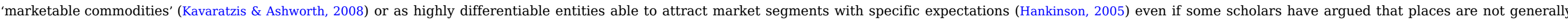

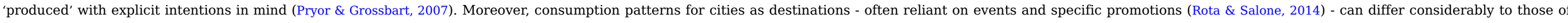

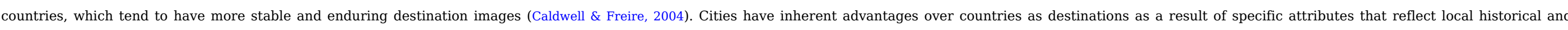
cultural intricacies (Landry, 2008; Rabbiosi, 2015; Warnaby, 2009).

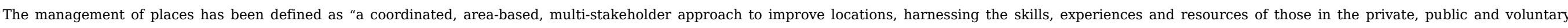




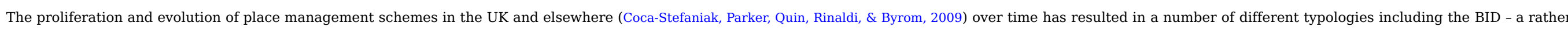

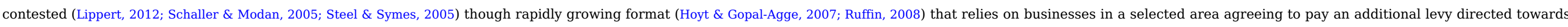
the amelioration of places (Peyroux, Pütz, \& Glasze, 2012).

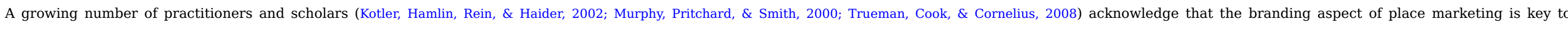

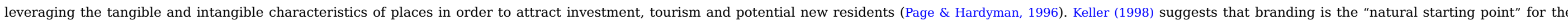

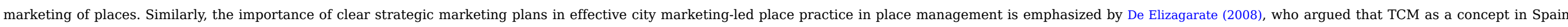

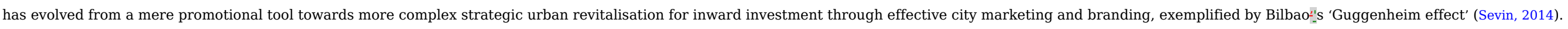

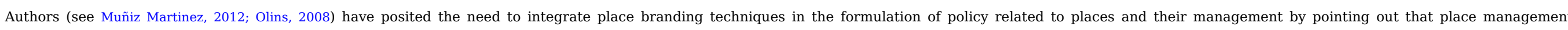

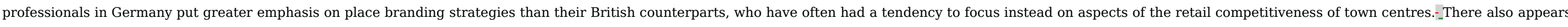

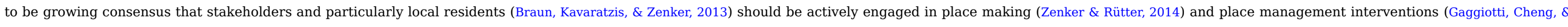

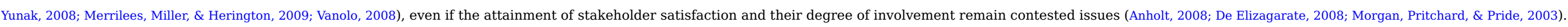

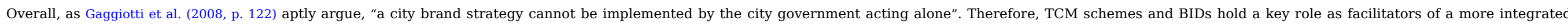
approach to urban planning and management (Säynäjoki, Inkeri, Heinonen, \& Junnila, 2014; Warnaby et al., 2005) that produces successful place brands. In view of this, they merit further discussion here.

\subsubsection{Town centre management}

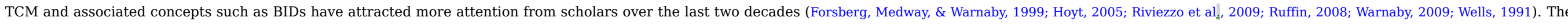

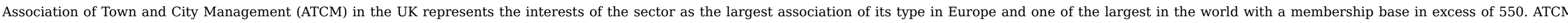

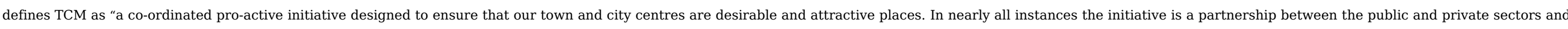

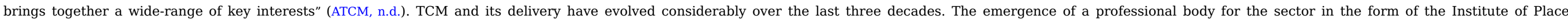

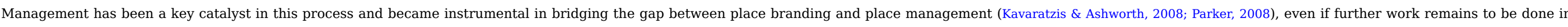
terms of incorporating innovative international practice in place management into the professionalization of the sector (Ruffin, 2008).

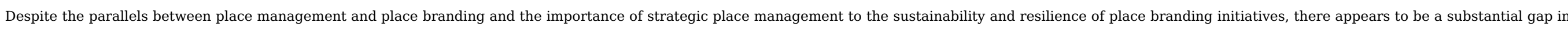

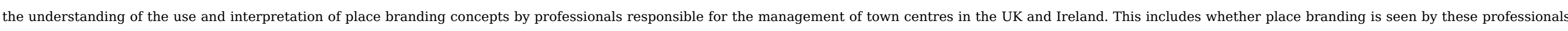

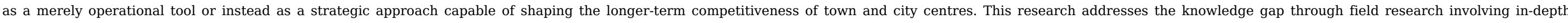
interviews with key professionals including town centre managers, BID managers and consultants in England, Wales, Northern Ireland and the Republic of Ireland.

\section{3 Methodology}

\subsubsection{Sampling and interviewee profile}

A total of 15 interviews were carried out with professionals in TCM and BIDs. A profile of the interviewees is provided in Table 1.

\section{Fable 1.Table 1 Profile of interviewees.}


Marketing and communication manager ( $\mathrm{CEO}_{-}^{\prime} \mathrm{s}$ spokesperson)

Executive director/director

Executive director/director

Director, marketing and communications

Managing director

Operations manager

Director, corporate development

$$
\text { CEO }
$$

CEO
Place branding and event management consultancy

Place branding and urban management consultancy

Trade association

Business Improvement District

Business Improvement District

Local authority

Business Improvement District

Business Improvement District/DMO

Business Improvement District

Destination Management Organisation (DMO)

Place branding consultancy

Business Improvement District

Business Improvement District

Business Improvement District

Town centre investments and retail planning
UK and overseas

UK and overseas

UK

West Midlands (England)

Southeast England

London

London

West Midlands (England)

East Anglia (England)

Northern Ireland and UK

UK

Eastern Ireland

Eastern Ireland

Eastern Ireland

Wales and Southeast England

\subsubsection{Interviewing procedures and questions}

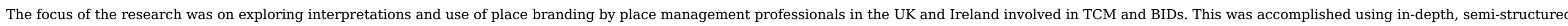

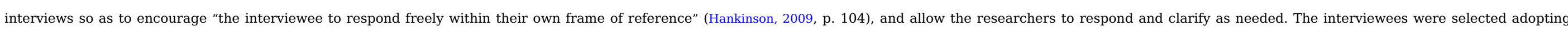

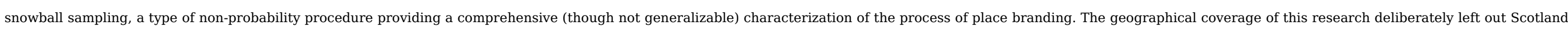
on the basis of differences related to the legislation pertaining to BIDs in that part of the UK.

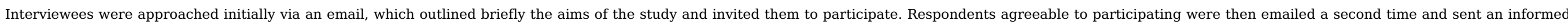
consent form, which outlined the objectives of the research and offered respondents anonymity in exchange for their participation.

\subsubsection{Response coding process}

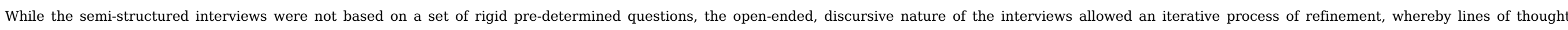

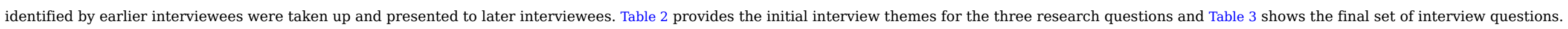

Fable 2.Table 2 Research objectives and themes.

alt-text: Table 2 .

a) To determine the role of place branding in the place development and management schemes.
- Views of place branding.

- Whether strategic or operational.

- Method of application in TCMs/BIDs. 
b) To examine to what extent the application of place branding is effective in developing and managing places.

c) To evaluate potential avenues for the future of place branding in place making

\section{Fable 3.Table 3 Interview questions.}

alt-text: Table 3.

Place branding role (research objective 1)

- What do you think place branding is in your opinion?

- Do you consider place branding strategic to place development and place management?

- How is place branding carried out in your BID/TCM? (Strategically or operationally?)

- Do you think the place branding activities have to be carried out by consultants rather than using the internal expertise? If yes, why?

Effectiveness (research objective 2)

- To what extent do you think your BID/TCM has been effective so far?

- How effective do you think the application of Place Branding has been in your BID?
- Extent of TCMs/BIDs effectiveness

- Extent of the effectiveness of place branding in TCMs/BIDs.

- Methods of enhancing effectiveness.

- Impact of political discontinuities on ongoing place branding activities.

- Difference place branding makes to TCMs/BIDs.

- Future role of place branding.

- How well embedded in policies of urban governance.

- Responsibility in carrying out place branding. 
- How do you think the TCM/BID schemes can more effectively apply place branding?

- Is it needed?

- What are the effects of political discontinuities on ongoing place branding activities and how do TCM/BID managers mitigate such effects?

Evaluating the future (research objective 3)

- What difference do you think place branding makes to a place management and place development project (in terms of benefits to the place/people?)

- What role do you think place branding will play in managing and developing places in the future?

- How well is this scheme embedded in the local borough-1 policy of urban governance?

- Who will be carrying these developments and applying to place branding (whether strategically/operationally)?

- How do you see this working out operationally or strategically for your place?

The interview data set contained more than 70,000 transcribed words and these data were analysed as follows:

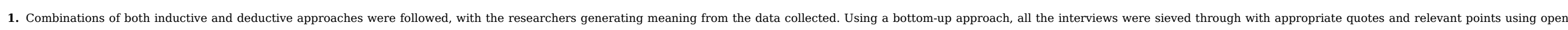
coding.

2. Axial coding was employed to classify similar themes together.

3. Themes were then grouped into three major themes/sets and sub-themes (Table 4) were also created for deeper analysis and understanding of the meanings.

able 4.Table 4 Example of sub-theme creation.

alt-text: Table 4.

\begin{tabular}{|c|c|c|}
\hline Sub-theme & Description & Example quotes \\
\hline \multirow{2}{*}{$\begin{array}{l}\text { Defining place } \\
\text { branding }\end{array}$} & \multirow{2}{*}{$\begin{array}{l}\text { Developing a place identity or place } \\
\text { DNA }\end{array}$} & "For me place branding is about creating a (.....) concise brand message and story for an area"(I-3) \\
\hline & & “..... place branding would be developing an identity for a location"(I-5) \\
\hline $\begin{array}{l}\text { Extending the } \\
\text { definition of place } \\
\text { branding }\end{array}$ & $\begin{array}{l}\text { Business mix (combining business, } \\
\text { history and culture to enhance place } \\
\text { branding) }\end{array}$ & $\begin{array}{l}\text { "... place branding would be developing an identity for a location (...) could be anything from the business mix to the public realm to the } \\
\text { (...) the sort of heritage and history (...) of the place and that is then used to promote it, to position it viz,-a-viz, the locations". (I-9) }\end{array}$ \\
\hline
\end{tabular}




\subsubsection{Place branding and stakeholder relationships}

The importance of stakeholder management was highlighted unanimously by participants $(n=15)$ as key in the place branding process

"For me, place branding is about creating a concise brand message and story for an area with all the relevant stakeholders involved". (I 3)

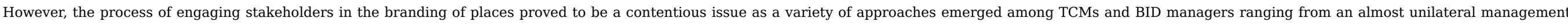
approach (I9) to one where branding responsibilities were split among stakeholders by geographical area and target audience (I5), as illustrated by the quotes below:

"We engage with our stakeholders in an informal way but they don:t sign things off or give us permission to do things. So we very much run the branding in the way we want to." (I9)

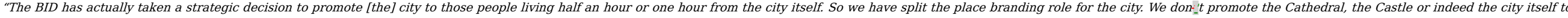
the wider tourist visitor. We are trying to engage with the people who live within an hour from the city." (I5)

There were also those who argued that highly focused approaches such as the ones outlined above may actually result in missed strategic opportunities for a more holistic branding of town and city centres:

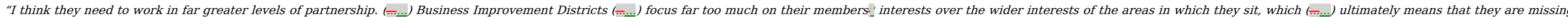
on opportunities for joint marketing of the city." (I6)

\section{5.}

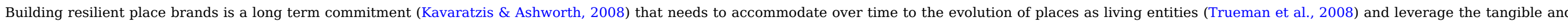
intangible traits of place (Kotler et al., 2002).

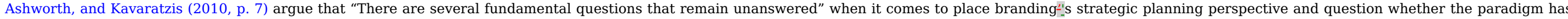

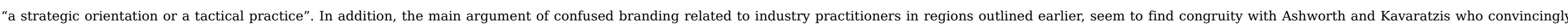
corroborate that "the non-geographical thinking of many commentators and practitioners who work in the field has led to confusion in terms of the social and spatial implications of place branding" (ibid).

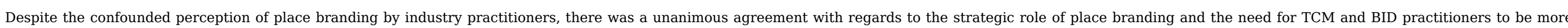

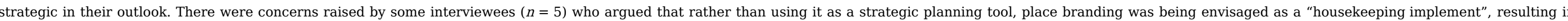

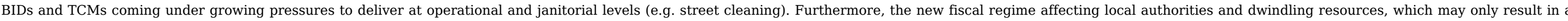

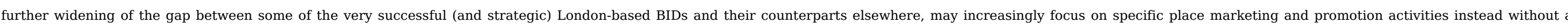

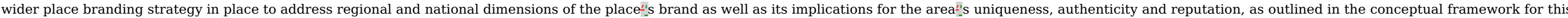
study (Figure. 1)

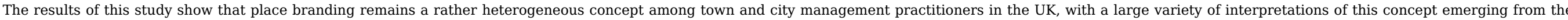

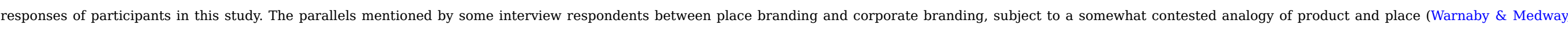

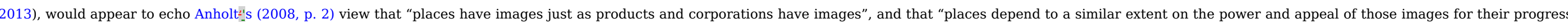
and prosperity."

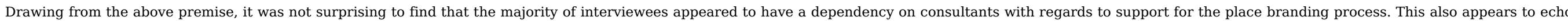

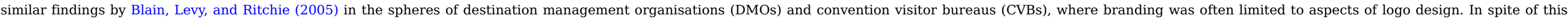

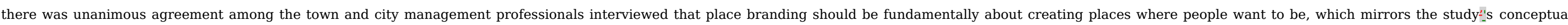
framework (Figure. 1) in as much as place experiences are intimately linked with place images as well as a sense of uniqueness and authenticity.

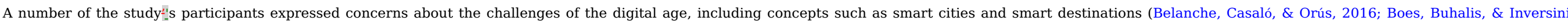



uniqueness of destinations around the world (Zhou \& Wang, 2014).

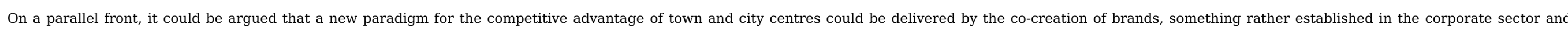

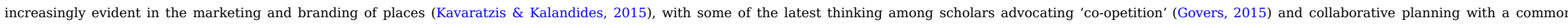

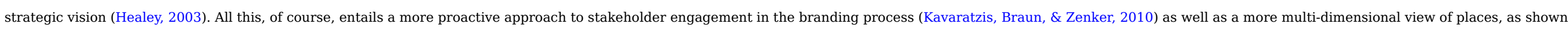
in this study!'s conceptual framework (Figure. 1).

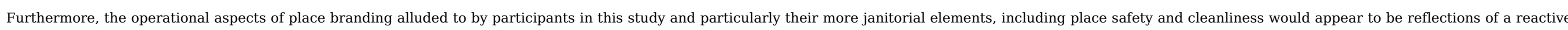

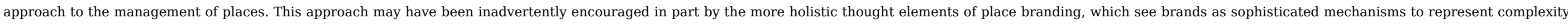

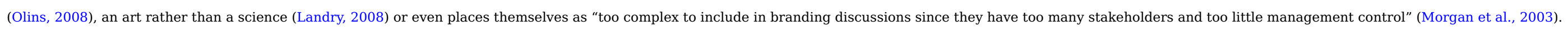

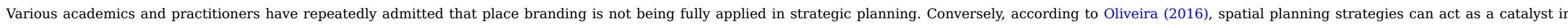
place branding interventions. This underpins our premise of place branding having a knitted affiliation with strategic planning with the involvement of local actors, citizens, policymakers and organizsations.

\section{6.}

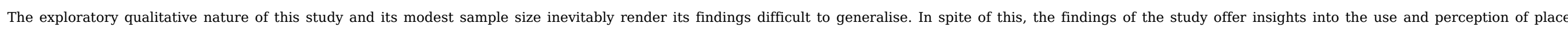

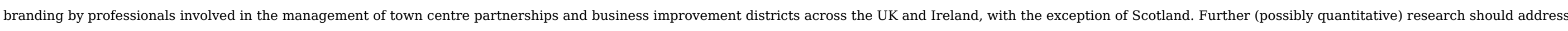

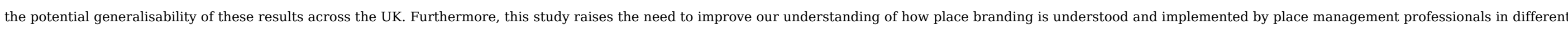

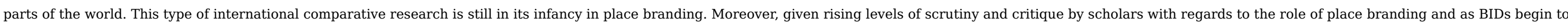

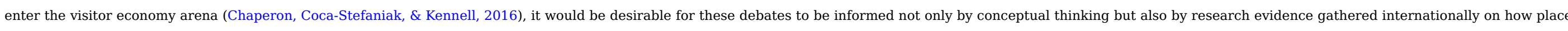

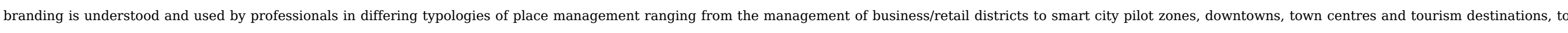

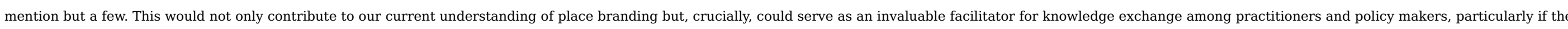

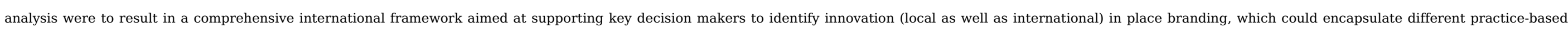

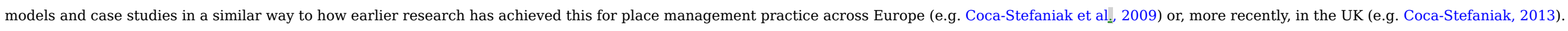

\section{Uncited references}

Govers, 2013

Kalandides, 2011

Kavaratzis, 2011

Warnaby et al., 1998

\section{References}

Anholt S., Place branding: Is it marketing, or isn-'t it?, Place Branding and Public Diplomacy 4 (1), 2008, 1-6.

Ashworth G.J., Should we brand places?, Journal of Town and City Management 1 (3), 2011, 248-252.

Ashworth G.J.G.J. and Voogd H., Marketing and place promotion, In: Place promotion: the use of publicity and marketing to sell towns and regions, $1994,39-52$.

Ashworth G. and Kavaratzis M., (Eds.), Towards effective place brand management branding European cities and regions, 2010, Edward Elgar; Cheltenham.

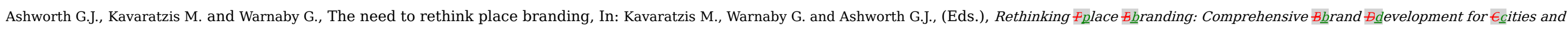


Fregions, 2015, Springer International Publishing; Cham, 1-12.

ATCM (n.d.), 'What is TCM?', Association of Town and City Management. (Online); Retrieved from https://www.atcm.org/about_atcm/what_is_tcm, (accessed on 5/01/2017). Avraham E., Media strategies for improving an unfavourable city image, Cities 21 (6), 2004, 471-479.

Avraham E. and Ketter E., Media strategies for marketing places in crisis: Improving the image of cities, countries, and tourist destinations, 2008, Routledge; London.

Balakrishnan, Strategic marketing of destinations: 丸ㅛ framework, European Journal of Marketing 3 (5--6), 2009, 611-629.

Belanche D., Casaló L.V. and Orús C., City attachment and use of urban services: Benefits for smart cities, Cities 50, 2016, 75-81.

Bell F., Looking beyond place branding: ŁThe emergence of place reputation, Journal of Place Management and Development 9 (3), 2016, $247-254$.

Blain C., Levy S. E.S.E. and Ritchie J. B.I.B., Destination branding: Insights and practices from destination management organizations, Journal of Travel Research 43 (4), 2005, 328-338.

Boes K., Buhalis D. and Inversini A., Smart tourism destinations: Ecosystems for tourism destination competitiveness, International Journal of Tourism Cities 2 (2), 2016, 108-124.

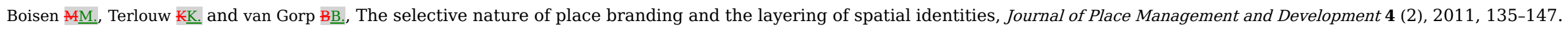

Braun E., Kavaratzis M. and Zenker S., My city-my brand: ŁThe different roles of residents in place branding, Journal of Place Management and Development $\mathbf{6}$ (1), $2013,18-28$.

Braun E., Eshuis J. and Klijn E.H., The effectiveness of place brand communication, Cities 41, 2014, 64-70.

Caldwell N. and Freire J., The differences between branding a country, a region and a city: Applying the brand box model, Journal of Brand Management 12 (1), $2004,50-61$.

Chan C.S. and Marafa L.M., A review of place branding methodologies in the new millennium, Place Branding and Public Diplomacy 9 (4), $2013,236-253$.

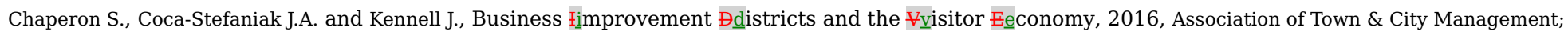

London http://gala.gre.ac.uk/14772/1/14772_Coca_Stefaniak_Business_improvement_districts_(pub_PDF)_2016.pdf, (accessed 21 March 2017).

Coca-Stefaniak J.A., Successful town centres - developing effective strategies, 2013, GFirst-ATCM;

Gloucester https://www.atcm.org/policy_practice/tools_dir/successful_town_centres_developing_effective_strategies, (accessed 21 March 2017).

Coca-Stefaniak J.A., Parker C., Quin S., Rinaldi R. and Byrom J., Town centre management models: A European perspective, Cities 26 (2), $2009,74-80$.

Costaglioli F. and Van Assche K., Silent places, silent plans: Silent signification and the study of place transformation, Planning Theory 11 (2), $2012,128-147$.

Davies R.L. and Bennison D.J., Retailing in the city centre:

De Elizagarate V., Marketing de Ciudades: Estrategias para el desarrollo de ciudades atractivas y competitivas en un mundo global, 2008, Esic; Madrid.

Dinnie K., (Ed), City branding: Theory and cases, 2011, Palgrave Macmillan; London.

Dinnie K., Melewar T.C., Seidenfuss K.U. and Musa G., Nation branding and integrated marketing communications: zAn ASEAN perspective, International Marketing Review 27 (4), $2010,388-403$.

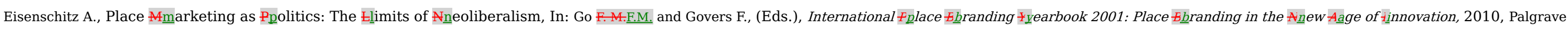
Macmillan; Houndmills, UK, 21-30.

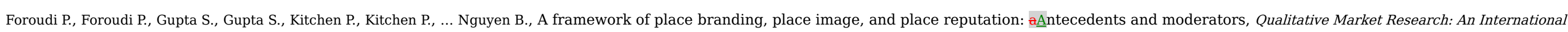
Journal 19 (2), 2016, 241-264.

Forsberg H., Medway D. and Warnaby G., Town centre management by co-operation: eEvidence from Sweden, Cities 16 (5), 1999, 315-322.

Gaggiotti H., Cheng P. and Yunak O., City brand management (CBM): The case of Kazakhstan, Place Branding and Public Diplomacy 4 (2), 2008, 115-123. 
Gertner D., Unfolding and configuring two decades of research and publications on place marketing and place branding, Place Branding and Public Diplomacy 7 (2), 2011 , 91-106.

Gnoth J., Leveraging export brands through a tourism destination brand, Journal of Brand Management $\mathbf{9}$ (4-5), 2002, 262-280.

Govers R., Why place branding is not about logos and slogans, Place Branding and Public Diplomacy 9 (2), 2013, 71-75.

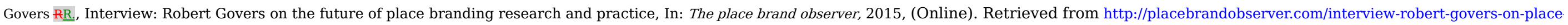
branding-research-and-practice/, (accessed 20/01/2017).

Hankinson G., Destination brand images: A business tourism perspective, Journal of Services Marketing 19 (1), 2005, 24-32.

Hankinson G., Managing destination brands: eEstablishing a theoretical foundation, Journal of Marketing Management 25 (1-_2), 2009, 97-115.

Hankinson G., The management of destination brands: Five guiding principles based on recent developments in corporate branding theory, Journal of Brand Management 14 (3), 2007, $240-254$.

Hankinson G., Place branding research: A cross-disciplinary agenda and the views of practitioners, Place Branding and Public Diplomacy 6 (4), $2010,300-315$.

Hannah and Rowley, Towards a strategic place brand management model, Journal of Marketing Management 27 (5--6), 2011, 458-476.

Healey P., Collaborative planning in perspective, Planning Theory 2 (2), 2003, 101-123.

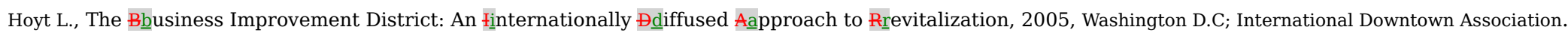

Hoyt L. and Gopal-Agge D., The business improvement district model: A balanced review of contemporary debates, Geography Compass 1 (4), $2007,946-958$.

Hubbard P. and Hall T., The entrepreneurial city and the 'new urban politics', In: The entrepreneurial city, 1998, 78.

Jackson L.A., Residents!-! perceptions of the impacts of special event tourism, Journal of Place Management and Development 1 (3), 2008, $240-255$.

Kalandides A., City marketing for Bogotá: æa case study in integrated place branding, Journal of Place Management and Development 4 (3), 2011, 282-291.

Kavaratzis M., From city marketing to city branding: Towards a theoretical framework for developing city brands, Place Branding 1 (1), $2004,58-73$.

Kavaratzis M., The dishonest relationship between city marketing and culture: Reflections on the theory and the case of Budapest, Journal of Town and City Management 1 (4), 2011, 334-345.

Kavaratzis M. and Ashworth G.J., City branding: ąAn effective assertion of identity or a transitory marketing trick?, Place Branding and Public Diplomacy 2 (3), 2006, 183-194.

Kavaratzis M. and Ashworth G.J., Place marketing: hH Hew did we get here and where are we going?, Journal of Place Management and Development 1 (2), $2008,150-165$.

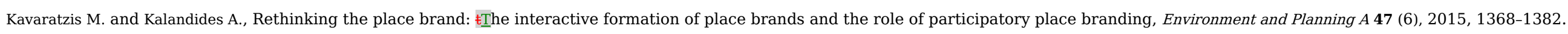

Kavaratzis M., Braun E. and Zenker S., In: My city-my brand: țThe role of residents in place branding, 50th European Regional Science Association Congress, Jönköping2010, 19-23.

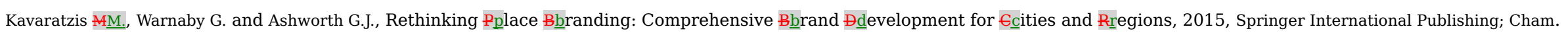

Keller K.L., Strategic brand management: $\underline{b}$ B uilding, measuring, and managing brand equity, 1998, Prentice Hall; New Jersey.

Kokosalakis C., Bagnall G., Selby M. and Burns S., Place image and urban regeneration in Liverpool, International Journal of Consumer Studies 30 (4), $2006,389-397$.

Kotler P. and Gertner D., Country as a brand, product and beyond: A place marketing and brand management perspective, Journal of Brand Management $\mathbf{9}$ (4-_5), 2002 , 249-261.

Kotler P., Hamlin M. A.M.A., Rein I. and Haider D.H., Marketing Asian places, 2002, John Wiley \& Sons; Singapore.

Landry C., The art of city making, European Planning Studies 16 (9), 2008, (pp.).

Lippert R., 'Clean and safe’ passage: Business İimprovement Đdistricts, urban security modes, and knowledge brokers, European Urban and Regional Studies 19 (2), 2012, 167-180. 
Llinares C., Page A. and Llinares J., An approach to defining strategies for improving city perception: Case study of Valencia, Spain, Cities 35, 2013 , 78-88.

Lucarelli A. and Berg P.O., City branding: $\underset{A}{A}$ state-of-the-art review of the research domain, Journal of Place Management and Development 4 (1), $2011,9-27$.

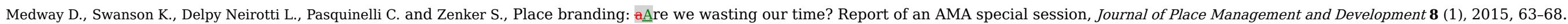

Merrilees B., Miller D. and Herington C., Antecedents of residents_-! city brand attitudes, Journal of Business Research 62 (3), $2009,362-367$.

Morgan N., Pritchard A. and Pride R., Destination branding: €CCreating the unique destination proposition, 2003, Butterworth-Heinemann; Oxford.

Muñiz Martinez N., City marketing and place branding: A critical review of practice and academic research, Journal of Town and City Management 2 (4), 2012, (pp.).

Murphy P., Pritchard M.P. and Smith B., The destination product and its impact on traveller perceptions, Tourism Management 21 (1), $2000,43-52$.

Neirotti P., De Marco A., Cagliano A.C., Mangano G. and Scorrano F., Current trends in Smart City initiatives: Some stylised facts, Cities 38, 2014, 25-36.

Olins W., Wally Olins: The brand book, 2008, Thames and Hudson; London.

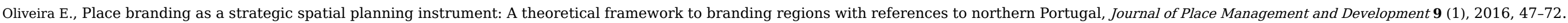

Page S.J. and Hardyman R., Place marketing and town centre management: ż A new tool for urban revitalization, Cities 13 (3), 1996, 153-164.

Parker C., Place - ŁThe trinal frontier, Journal of Place Management and Development 1 (1), 2008, 5-14.

Parkerson B. and Saunders J., City branding: ę- $a n$ goods and services branding models be used to brand cities?, Place Branding and Public Diplomacy 1 (3), 2005, 242-264.

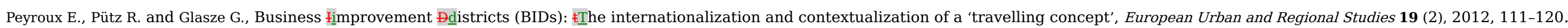

Pike S., Tourism destination branding complexity, Journal of Product and Brand Management 14 (4), 2005, 258-259.

Pryor S. and Grossbart S., Creating meaning on main street: Towards a model of place branding, Place Branding and Public Diplomacy 3 (4), 2007, 291-304.

Qu H., Kim E. H.L.H. and Im H.H.H.H., A model of destination branding: Integrating the concepts of the branding and destination image, Tourism Management 32 (3), 2011 , 465-476.

Rabbiosi C., Renewing a historical legacy: Tourism, leisure shopping and urban branding in Paris, Cities 42, 2015, 195-203.

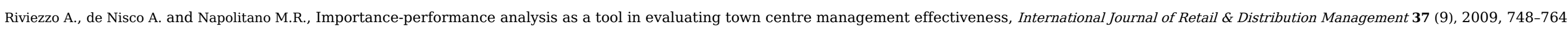

Rota F.S. and Salone C., Place-making processes in unconventional cultural practices: The case of Turinz's contemporary art festival Paratissima, Cities 40, 2014 , 90-98.

Ruffin F., Professionalizing business district management for the twenty-first century, Journal of Place Management and Development 1 (1), 2008, 29-45.

Säynäjoki E.S., Inkeri V., Heinonen J. and Junnila S., How central business district developments facilitate environmental sustainability - A multiple case study in Finland, Cities 41, 2014 , 101-113.

Scaramanga M., Talking about art(s) - A theoretical framework clarifying the association between culture and place branding, Journal of Place Management and Development 5 (1), $2012,70-80$.

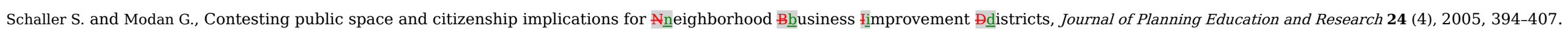

Sevin H.E., Understanding cities through city brands: City branding as a social and semantic network, Cities 38, 2014, 47-56.

Skinner H., The emergence and development of place marketing

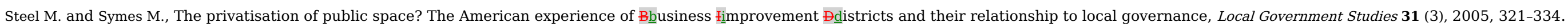

Stubbs B., Warnaby G. and Medway D., Marketing at the public/private sector interface: Town centre management schemes in the south of England, Cities 19, 2002, 317-326.

Tallon A., Urban Rregeneration in the UK, 2013, Routledge; London. 
Tasci and Gartner, A practical framework for destination branding, In: Tourism theory and practice, 1, 2009, 149-158.

Trueman M., Cook D. and Cornelius N., Creative dimensions for branding and regeneration: Overcoming negative perceptions of a city, Place Branding and Public Diplomacy 4 (1), $2008,29-44$.

Vanolo A., The image of the creative city: Some reflections on urban branding in Turin, Cities 25 (6), 2008, 370-382.

Vanolo A., Smartmentality: The smart city as disciplinary strategy, Urban Studies 51 (5), 2014, 883-898.

Warnaby G., Look up! Retailing, historic architecture and city centre distinctiveness, Cities 26 (5), 2009, 287-292.

Warnaby G., Bennison D. and Davies B.J., Marketing town centres: Retailing and town centre management, Local Economy 20 (2), 2005, 183-204.

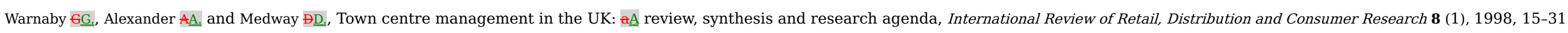

Warnaby G. and Medway D., What about the 'place' in place marketing?, Marketing Theory 13 (1), 2013, 345-363.

Wells I., Town centre management: A future for the high street?, 1991, University of Reading; Reading.

Whyatt G., Town centre management: $\mathrm{h}$ How theory informs a strategic approach, International Journal of Retail and Distribution Management 32 (7), $2004,346-353$.

Zavattaro S.M. and Adams F.G., Bridging the gap: An exploration of how DMO managers use education to overcome challenges, Urban Studies 53 (4), 2016 , 669-688.

Zenker S. and Rütter N., Is satisfaction the key? The role of citizen satisfaction, place attachment and place brand attitude on positive citizenship behaviour, Cities 38, $2014,11-17$.

Zenker S., Braun E. and Petersen S., Branding the destination versus the place: The effects of brand complexity and identification for residents and visitors, Tourism Management $\mathbf{5 8}, 2017,15-27$.

Zhou L. and Wang T., Social media: A new vehicle for city marketing in China, Cities 37, 2014, 27-32.

Zhao Y., 'China

\section{Highlights}

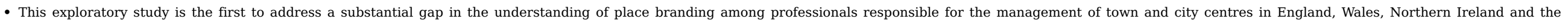
Republic of Ireland

- Field research was done with professionals in place management, including town centre management partnerships and business improvement districts (BIDs).

- The results of the study suggest that the strategic potential of place branding is negatively affected by a focus on operational thinking, which hinders innovation towards more holistic approaches to place management.

\section{Queries and Answers}

Query:

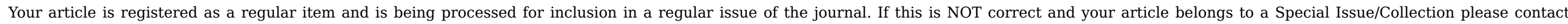
g.dheepa@elsevier.com immediately prior to returning your corrections.

Answer: Yes

Query:

Please confirm that given names and surnames have been identified correctly and are presented in the desired order, and please carefully verify the spelling of all authors' names. 
Answer: Yes

Query:

Please check whether the designated corresponding author is correct, and amend if necessary.

Answer: The designated corresponding author is correct

Query:

Highlights should only consist of 125 characters per bullet point, including spaces. The highlights provided are too long; please edit them to meet the requirement.

Answer: This study addresses a substantial gap in the understanding of interpretations of place branding among place management professionals in the UK

The research suggests that the strategic potential of place branding is hindered by a generalised focus on operational thinking

Query:

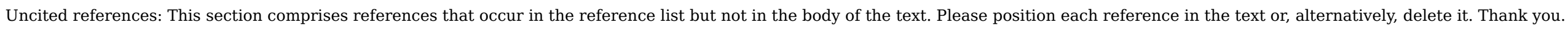

Answer: Please delete the uncited references highlighted

Query:

Please supply the year of publication.

Answer: Year of publication: 2016 